\title{
Influence of Hate Speech on Public Perception of Presidential Candidates' Credibility During the 2015 Presidential Election in Nigeria
}

\author{
Christian Alozie Ogbonna ${ }^{1}$, Professor Nnanyelugo Okoro ${ }^{1} \&$ Joseph O. Wogu ${ }^{1}$ \\ ${ }^{1}$ Department of Mass Communication, University of Nigeria, Nsukka, Nigeria \\ Correspondence: Joseph O. Wogu, Department of Mass Communication, University of Nigeria, Nsukka, Nigeria
}

Received: January 15, 2020 Accepted: February 20, 2020 Online Published: March 11, 2020

doi:10.5539/gjhs.v12n5p20 URL: https://doi.org/10.5539/gjhs.v12n5p20

\begin{abstract}
The study examines the influence of hate speech on public perception of presidential candidates' credibility during the 2015 presidential election in Nigeria. The study was guided by two research questions. A descriptive survey design was adopted for the study using 72,001, 204 eligible registered voters in the six geo-political zones of Nigeria. 600 questionnaires were distributed and 518 were returned for analysis through multi-stage sampling. The research questions were answered using mean and standard deviation, while the hypotheses were tested using Pearson - chi-square test at 0.05 level of significance. Findings reveal that the extent to which voters were aware of hate speech against a political opponent during the 2015 presidential election in Nigeria was high. The findings further show that one of the factors that influenced hate speech against a political opponent during the 2015 presidential election in Nigeria was the political affiliation of voters. Concerning the null hypotheses, findings indicated that there was no significant relationship among the responses of the electorate in the six geo-political zones on the factors that influenced hate speech during the 2015 presidential election in Nigeria. A significant relationship was also not found on how hate speech influenced public perception of presidential candidates during the 2015 presidential election in Nigeria. The study recommends that politicians, political parties as well as their supporters should be cautioned on using social media to post hate speech, inciting messages, attack opponents, spread false news. The Independent National Electoral Commission (INEC) should propose to the National Assembly to enact laws in the electoral act that will make the use of hate speech for campaign purposes a punishable offence in the country.
\end{abstract}

Keywords: hate speech, public perception, presidential candidates, credibility, Presidential Election and Nigeria

\section{Introduction}

Since the return of a democratic type of government in Nigeria in 1999, many political events have evolved, each contesting to be entrusted with the affairs of the State. It seems normative for political campaigns or speeches delivered to the citizens or public, personally or by way of radio, television or the internet, to be laced with streams of hate language. Ekanola (2006) describes Nigeria as an anomalous entity in which various ethnic groups that represent the country have no shared history, way of life or language, such that members of specific groups are easily identified through their attributes. Suberu (2006) argues that the absence of collective identity by way of ethnic groups in Nigeria worsens its experience of hate-speech. Thus, it is the search for ethnic identity and intolerance of the group regarded as 'outsider' that informs manifestations of hate-speech in Nigeria. Hate speech is depicted as discourse, action or direct, composing, or exhibit which is unlawful in the light of the reality that it actuates brutality or biased undertaking against or by way of a secured gathering or individual primarily based on their enrollment of the gathering, or because it criticizes or scares an ensured gathering, or person based totally on their participation to a gathering. Essentially, such speeches rob others of their dignity. Therefore, United Nation (2016) opined that hate speech includes: (a) all dispersal of ideas established on racial or ethnic occurrence or disdain, by anything implies; (b) induction to scorn, disdain or oppress others from a gathering on the ground of their race, shading, plunge, or countrywide or ethnic starting point; (c) risks or prompting to savagery against human beings or gatherings on the grounds in (b) above; (d) articulation of put-down, criticism or defamation of humans or gatherings or support of contempt, hatred or separation on the grounds in (b) above, when it unmistakably sums to impelling to disdain or segregation; and (e) interest in associations and exercise which strengthen and actuate racial segregation. 
Political speeches and campaigns have become venoms that poison the minds of the people and incite them to violence. The political, religious and cultural gaps that separate the various ethnic groups that make up the teeming populace of Nigeria have been widened due to unbridled use of hate speech.

The violent use of words in political speech influences people who are aggressive to take part in politics and foster violent political actions. Benesche (2015) definitions of hate speech appear to concur with the above view. She defines hate speech as an unsafe speech which denigrates humans based on their membership of a group, religious affiliations or ethnicity. She identifies 4 key variables for identifying hate speech: the level of a speaker's personality; the extent a speaker influences initiation of violence; the social and historic context; how the speech is disseminated.

Speech is an instrument for communication. The beginning of the universe was the establishing of communication. There was no beginning which was devoid of communication. Thus, conversation enables the transformation of human society. Communication is a many-sided phenomenon that means different matters to distinctive people. It is a process of a means of access to the mind or thoughts of another.

Explaining the pivotal position the media play in propelling hate speech in the society, each Habermans (2006) and Castell (1994) posit that there is the underlying assumption of a pivotal role which the mass media play in politics and political participation. Habermans similarly argue that the mass media are an integral part of political power in any society. The media mediate and they do now not stand unbiased of a given social gadget but furnish channels of verbal exchange between elements inside it. Randall (2008) notes that the mass media also acts as a platform thru which people and pastime companies in the society categorical their views. The media are universally referred to as sellers of electricity and political control, such that these who hold sway of political strength and authority are constantly conscious of the reality that records management and control are central to capturing, holding and exercising of political power. The implication of this is that the ownership, manipulate and accessibility to the media are regarded indispensable to the wielding and sustenance of political power. This recognition of the mass media as sellers of power and political manage is partly accountable for the choices of the government of growing international locations (Nigeria inclusive) to both very own their media or alter news and records drift inside their nations (Sussmman, 1989).

Several previous studies on hate speech have shown that the media are powerful agenda setters for the public and have significantly impacted on the political process globally. Thus, the media are often deployed by different political interests group in the society to achieve power leverage and spread hate speeches (Ezeibe,2015). The 2015 presidential election which offered hope and a moment for reflection in Nigeria, has come and gone but the different events and issues surrounding the elections are still being discussed by scholars. However, scholars have observed that within the campaign period of the election, many hate speeches were deployed by the political class in the country. Most of these derogatory speeches and advertorials both in print and broadcast media were freely used by members of the two leading political parties in the country-Peoples Democratic Party (PDP) and All Progressives Congress (APC) among other parties.

The 2015 presidential election which offered hope and a moment for reflection in Nigeria have come and gone but the different events and issues surrounding the elections are still being discussed by scholars. However, scholars have observed that within the campaign period of the election, many hate speeches were deployed by the political class in the country. Most of these derogatory speeches and advertorials both in print and broadcast media were freely used by members of the two leading political parties in the country.

The main objective of any political party all over the world is to win election and access state power (Ezeibe, 2015). In the quest for power, political parties and their candidates make extensive use of the mass media to reach the electorate and market their candidates and manifestoes. For instance, it was estimated that media buying for political purposes cost both Peoples Democratic Parties (PDP) and All Progressives Congress (APC) over one billion Naira during the 2015 presidential election campaigns. This was essentially done to drive home their claims and programmes. In Nigeria, political parties use the mass media mostly to de-market their opponents and achieve electoral victory.

During the 2015 elections, violent political metaphor such as framing of electoral participation in violent terms and political backlash were freely and extensively used by the politicians to discredit their opponents. These hate speeches, come in the form of advertorials, name-calling, mudslinging and other forms of abusive language which in turn heightened the level of political instability. Despite global outcry on the negative consequences of hate speech in democratic settings, political parties and their candidates still use hate speech to discredit their opponents in a bid to claim power. Hate speech has been identified to have a lot of influence on the electorate. 
Although there exists copious literature on the influence of hate speech on the political process (Ezeibe, 2013), none seems to have specifically examined its influence on the credibility of presidential candidates of various political parties during 2015 presidential election. This study attempts to assess the influence of hate speech on public perception of presidential candidates' credibility during the 2015 presidential election in Nigeria.

The paper seeks to determine the influence of hate speech on public perception of presidential candidates' credibility during the 2015 general election in Nigeria. Specifically, the study seeks to:

1. Ascertain the extent to which voters were aware of hate speech against political opponents during the 2015 presidential election in Nigeria.

2. Determine factors that influenced hate speech during the 2015 election in Nigeria.

\section{Theoretical and Empirical Review}

The theoretical bedrock of this research is the social responsibility theory. The Hutchins Commission on freedom of the Press (1947) produced the social responsibility theory. As a normative theory, social responsibility theory explains how media should ideally operate in a given society of social values and it is the standard against which the public judges. This theory asserts that media must remain free of government control, but in exchange, the media must serve the public. In the performance of this stewardship function through reportage of events and crisis, the social responsibility theory emphasizes that the media must keep with the professional standards of truth, objectivity, accuracy, and balance in order not to further aggravate the crisis situation.

The theory emphasizes that the mass media in their reports must not promote violence and civil disorder or be biased in favour of one minority group while relegating the views or accessibility of other minor or major groups to the background. The media as a whole should be pluralistic and reflect the diversity of their society, given access to various points of view and right to reply as well as the social welfare of the people.

In relation to this study, it is apparent that the various mass media in the country have failed in their social responsibility to the society. The various media platforms were used to propagate hate speeches during the 2015 presidential campaign in Nigeria. These hate speeches either instigated the people against a political candidate or a political, religious or ethnic group.

Again, Lakoff (2012) reinforces this notion when heavers that the wounding message of hate speech goes beyond "mere words" that are slurs and fighting words... Words, he maintains, are world-changing and carry in themselves the ability to transform the world. Lakoff further argues that to say that speech is not action is to commit what he calls the logical error of drawing a sharp distinction between the mind and the body' Speech, he says, 'is the thin line between thoughts and action'.

Notably, Nigeria's political history has been very unstable. Election violence in Nigeria dates back to the pre-colonial era, through the first, Second, and Third Republics to the fourth Republic in 1999. Violence has become a regular character of election such that the democratic process, values and institutions are prevented from developing because power is gained and retained through violence. The proliferation of small arms and peddling of hate speeches sustain the culture of intolerance and electoral violence in Nigeria. It is pertinent to observe that electoral violence in Nigeria manifests in the form of killings, lootings, destruction and damage of properties; assault and death threats; bombings; forceful dispersion of political rallies; destruction of campaign billboards, fighting among political parties; violent street protests and hooliganism; arbitrary detention and arrest without warrant and abduction. These manifestations threaten democratisation in Nigeria.

Electoral violence is linked to electoral fraud and ethnicity in Nigeria. Electoral fraud survives because successive political generations in Nigeria have the impression that politics is a lucrative business. Most individuals and groups, therefore, seek political power for personal aggrandisement and this ambition is often pursued at all costs (Ejiofor, 2007).

Notably, the 2011 presidential election was the first genuine political contest between the predominantly Christian South and the Muslim North since Nigeria was swept into the "third wave" of democratisation. The presidential election divided the country along ethnic and religious lines. Violence during the party primaries, campaigns and Election Day resulted in the death of at least 165 people (Human Rights Watch, 2011). Meanwhile, the report of the National Human Rights Commission (NHRC) in 2015 showed that hate speech preceded the 2015 presidential election and this accounted for the high level of pre-election violence. Adibe (2015) agrees that hate speech is a catalyst for violence.

\section{Methodology}

The descriptive survey research design was adopted in the study The population of this study comprised all the 
72,001,204 eligible registered voters in the six geo-political zones of the 2014-2015 Independent National Electoral Commission's Voters Register. The source of information is from (INEC, 2015). The sample size for this study was 600 eligible voters from the six geo-political zones. The sample size was arrived at by using the Creative Research System online sample size calculator with a confidence level of $95 \%$. The calculator can be accessed via this website: http://www.surveysystem.com/sscalc.htm.

The study adopted the proportionate stratified sampling technique because the population is large and widely spread. To this end, the researcher used the technique to group the country (Nigeria) into six strata (North- East, North West, North Central, South-East, South-South, South-West). The researcher adopted the simple random sampling technique to select one state each from the six geo-political zones. The decision is hinged on of studies carried out by (Digital Consulting International, 2014; Okoli, 2015; Mbakwe,2016) that indicate the selected states with their capital have the highest number of political activities in the build-up of 2015 presidential election were hate speech were deployed during campaigns by contesting candidates. Therefore: North East -Borno State, North West-Kano State, North Central-FCT, Abuja, South East- Enugu, South-South-River state, South-West-Lagos State. Simple random ensures that every individual in the population has an equal probability of being selected as element. It equally ensures self-monitoring of element. The copies of the instruments were administered with the help of the six research assistants. They were briefed about the purpose of the study. The briefing process lasted for two days and in each of the days, day- one was how to go about administering the instruments was discussed. Day two the collation process was addressed. The trained research assistant was made up of people who are familiar with the selected states. One expert was from Measurement and Evaluation Unit, Faculty of Education, University of Nigeria, Nsukka, two from the Department of Mass Communication, Faculty of Art, University of Nigeria. The experts examined the items on the draft questionnaire in terms of clarity of the statements, importance of the content and suitability of the rating scale adopted. The responses between the first and the second tests. In line with this, the researcher with the help of research assistants administered a total of 5 copies of the questionnaire to 5 eligible voters in Oji River Local Government Area, Enugu state, the choice of Oji River local government area was because the population have homogeneity with the study area and population in terms of historical and socio-cultural backgrounds, adherence to religion, belief values, norms and social ceremonies. After two weeks, the researcher repeated the exercise. The data obtained from the two tests were then subjected to the main reliability test using Pearson $r$ Correction coefficient statistical procedure. The calculation formula for $r$ is:

$$
\text { Formula: } r=\frac{N \sum x y-\sum x \sum y}{\sqrt{\left[N \sum x^{2}-\left(\sum x\right)^{2}\right]\left[N \sum y^{2}-\left(\sum y\right)^{2}\right]}}
$$

Where:

$x=$ variable $x$

$y=$ variable $y$

$\sum=$ Summation of variables

$\mathrm{N}=$ population of the subject measured on both variables

Table x: Calculating Reliability of the Instrument

\begin{tabular}{|l|l|l|l|l|l|}
\hline $\mathbf{N}$ & $\mathbf{1}^{\text {st }}$ test $(\mathbf{X})$ & $\mathbf{2}^{\text {nd }}$ test $(\mathbf{Y})$ & $\mathbf{X}^{\mathbf{2}}$ & $\mathbf{Y}^{\mathbf{2}}$ & $\mathbf{X Y}$ \\
\hline 1 & 3 & 4 & 9 & 16 & 12 \\
\hline 2 & 9 & 9 & 81 & 81 & 81 \\
\hline 3 & 5 & 5 & 25 & 25 & 25 \\
\hline 4 & 4 & 3 & 16 & 9 & 12 \\
\hline 5 & 4 & 4 & 16 & 16 & 16 \\
\hline Total & $\mathbf{2 5}$ & $\mathbf{2 5}$ & $\mathbf{1 4 7}$ & $\mathbf{1 4 7}$ & $\mathbf{1 4 6}$ \\
\hline
\end{tabular}

$\mathrm{N}=5$

$\sum X=25$

$\sum Y=25$

$\sum X Y=146$

$\sum X^{2}=147$

$\sum Y^{2}=147$ 
$\left(\sum X\right)^{2}=625$

$\left(\sum Y\right)^{2}=625$

$$
\begin{gathered}
r=\frac{N \sum x y-\sum x \sum y}{\sqrt{\left[N \sum x^{2}-\left(\sum x\right)^{2}\right]\left[N \sum y^{2}-\left(\sum y\right)^{2}\right]}} \\
r=\frac{5(146)-(25)(25)}{\sqrt{[5(147)-625][5(147)-625]}} \\
r=\frac{730-625}{\sqrt{[735-625][735-625]}} \\
r=\frac{105}{\sqrt{[110][110]}} \\
r=\frac{105}{10.5 \times 10.5} \\
r=\frac{105}{110.2}=0.95
\end{gathered}
$$

The reliability coefficient index of 0.95 was obtained which shows that the instrument used for the study

The quantitative data was collected for one month with the help of six research assistants. The researcher monitored and was in constant touch with the research Assistants to ensure the effective gathering of data. The research assistant was briefed by the researcher on the objective, guidance, approach and the need to explain to the respondent on how to fill the questionnaire to reduce mortality that may arise fro the respondents. The data was collected through face -to- face administration with the efforts at ensuring full return rate. For analysis of generated quantitative data through the questionnaire, statistical package for Social Science (SPSS) version 20.0 was used. This was to obtain frequencies, percentages and other statistical measures of central tendencies such as mean and standard deviation in the initial analysis. The hypotheses were subjected to empirical test statistical significance. The Pearson Chi-square $\left(X^{2}\right)$ was used to establish the relationship between the variables. Again chi-square was used to test similarities or agreement between what was expected and was observed in other to determine the significance of such agreement or disagreement. The test was carried out at 20 degree of freedom (df) and 0.05 (5\%) level of significance. Meanwhile, a null hypothesis was not rejected if the significant value is greater than 0.05 level of significance, but rejected, if the significant value is less than 0.05 level of significance. Eventually, the researcher used descriptive statistical tools such as tables, pie-chart, percentages, mean, standard deviation and Pearson as inferential statistics to analyze and interpret the data. The interpretational analysis was linked to the 5 research objectives as well as the hypotheses to determine answers to the research questions. Excel sheet was used to code responses from the field for easy understanding.

\section{The Preponderance of Hate Speech in the 2015 Presidential Election}

Political leaders in Nigeria use hate speech to divide and rule the people already divided along ethnic and religious lines. Thus, they employ hate speech in politicking and this incites coexisting ethnic and religious groups, thereby generating all forms of violence especially election-related ones. The use of hate speech in Nigeria dates back to the pre-independence era but the colonial administration used the big whip to manage its negative manifestation. After Nigeria's independence, the First Republic politicians employed hate speech fiercely. Some of the earliest notable hate speeches credited to the First Republic politicians in Nigeria include the following:

* The Igbos are too dominating, if you employ an Igbo man as a labourer, he will like to take-over as a foreman within a short while - Late Sardauna of Sokoto, Sir Ahmadu Bello.

* The God of Africa has created the Igbo nation to lead the children of Africa from the bondage of ages - The first President of Nigeria, Dr Nnamdi Azikiwe.

* NnamdiAzikiwe's policy was to corrode the self- respect of the Yoruba people as a group to build up the Igbos as a master race - Chief Obafemi Awolowo (Seng \& Hunt, 1986).

Our interviews revealed that these hate speeches in Nigeria laid the foundation for the first military coup and counter-coup; 1964/1965 electoral violence especially in Western Nigeria; pogroms and civil war (1967-1970). The hate speeches identified above painted the Igbos as a dominant race, superior race and threat to the Yorubas. No wonder, the Igbos' were the major victims of the pogroms and the civil war in Nigeria. Although successive military governments in Nigeria suppressed hate speeches and their negative manifestations we note that during 
1979, 1993 and 1999 elections, the use of hate speeches was reawakened and this, increased since May 2010 after the death of President Musa Yaradua and the abandonment of PDP's arrangement of zoning public offices between the North and South.

Although that Nigeria has adequate legal frameworks (Constitution of Nigeria, 1999; Electoral Act, 2010; Political Party Code of Conduct, 2013 etc) to check hate speech and hate campaign, political leaders and their ethnic/religious supporters continue to use hate speech as a campaign strategy. Some of the notable hate speeches in Nigeria from 2010 to 2015 are shown in table 2 and 3. Table 2 shows the litany of hate speeches credited to the religious, political and ethnic leaders in Northern Nigeria.

The election campaign in the country has always been uneasy and sometimes laced with violence and killings in the different parts of the country. The 2015 presidential elections witnessed a series of hate speeches being used by politicians against their opponents. The election witnessed a huge speech attacks against individuals and groups. This was confirmed by the report by the Chairman of the National Human Rights Commission (NHRC), Prof.ChidiOdinkalu, who states that the 2015 general elections witnessed a rise in hate speeches during the campaign before the election. Ukwueze and Uche (2015) also reported that, before the 2015 General Elections in Nigeria, many political watchers, local and international observers and, of course, the entire citizenry were concerned about the spate of hate speeches that characterized the political campaign messages and adverts of the two main political parties. As a result of this, there was palpable fear that Nigeria's State was on the edge of a precipice. This worrisome trend led to the suing for peace by both the local and international community. This culminated in the signing of a peace deal popularly referred to as the Abuja Peace Accord"

Ayo-Aderele (2015) in an article published by Punch Newspapers on March 10, 2015, with the caption ", When Hate Speeches Threaten an Election", decries the hate speeches that characterized political campaigns in Nigeria, from the uncouth to the uncultured and damming statements emanating from both camps, Nigeria could not have had anything worse in recent times as far as campaigns are concerned. He also adds that "The personal attacks are not limited to sardonic jabs; the psychological war has been deployed in media advertisements, social media spaces and in extreme cases, inter-personal discussions"

Hate speech can also involve attacks on a person or group based on attributes such as gender, ethnic origin, religion, race, disability sexual orientation. In law, hate speech is any speech, gesture or conduct, writing or display which is forbidden because it may incite violence or prejudicial action against or by a protected individual or group or because it incites violence or prejudicial action against or by a protected individual or group or because it disparages or intimidates a protected individual or group. The law may identify a protected group by certain characteristics (Nockleby, 2000).

Table 1. Selected Prominent Hate Speeches During, 2015 Presidential Election in Nigeria

\begin{tabular}{|c|c|c|c|c|}
\hline $\mathbf{S} / \mathbf{N}$ & Year & Hate speaker & Hate speech & Sources \\
\hline 1 & 2010 & $\begin{array}{l}\text { The former Governor of } \\
\text { the old Kaduna State, } \\
\text { AlhajiLawanKaita }\end{array}$ & $\begin{array}{l}\text { The North would make the country ungovernable if } \\
\text { President Goodluck Jonathan wins the } 2011 \text { polls... } \\
\text { Anything short of a Northern President is tantamount } \\
\text { to stealing our presidency. }\end{array}$ & Jason, 2011 (See references) \\
\hline 2 & 2010 & $\begin{array}{lrr}\text { Shehu } & \text { Sani, a } & \text { Kaduna } \\
\text { based civil rights } \\
\text { activist }\end{array}$ & $\begin{array}{l}\text { President Goodluck Jonathan should not contemplate } \\
\text { contesting the } 2011 \text { presidential election. Any attempt } \\
\text { by him to contest amounts to incitement and a recipe } \\
\text { for political instability }\end{array}$ & $\begin{array}{l}\text { www.nigerianbestforum.com./s } \\
\text { hehu-sani-warns-jonathan-agai } \\
\text { nst-contesting }\end{array}$ \\
\hline 3 & 2010 & $\begin{array}{l}\text { National Coordinator of } \\
\text { the Coalition of } \\
\text { Northern Politicians, Dr } \\
\text { Junaidu Mohammed }\end{array}$ & $\begin{array}{l}\text { It must be a Northerner or no Nigeria... If Goodluck } \\
\text { Jonathan wins the PDP's endorsement to contest the } \\
2011 \text { presidential election, there would be violence. }\end{array}$ & $\begin{array}{l}\text { Interview with } \quad \text { Guardian } \\
\text { Newspaper, } 2^{\text {nd }} \text { November } 2010\end{array}$ \\
\hline 4 & 2011 & $\begin{array}{l}\text { Presidential Candidate } \\
\text { of Congress for } \\
\text { Progressive Change, } \\
\text { General } \\
\text { MuhammaduBuhari }\end{array}$ & $\begin{array}{l}\text { God willing, by } 2015 \text {, something will happen. They } \\
\text { either conduct a free and fair election or they go a very } \\
\text { disgraceful way. If what happened in } 2011 \text { should } \\
\text { again happen in } 2015 \text {, by the grace of God, the dog } \\
\text { and the baboon would all be soaked in blood. }\end{array}$ & $\begin{array}{l}\text { Reported by LikaBinniyat } \\
\text { Vanguard Newspaper on May } \\
15^{\text {th }}, 2012\end{array}$ \\
\hline
\end{tabular}




\begin{tabular}{|c|c|c|c|}
\hline 5 & 2012 & $\begin{array}{l}\text { National Coordinator of Unless efforts are made to ensure that the } 2015 \\
\text { the Coalition of general election is free and fair, it may turn out to be } \\
\text { Northern Politicians, Dr the last election in the history of the nation. } \\
\text { Junaidu Mohammed }\end{array}$ & Leadership March 29, 2012 \\
\hline 6 & 2013 & $\begin{array}{l}\text { National Coordinator of There will be bloodshed. Those who feel } \\
\text { the Coalition of short-changed may take the war path and the country } \\
\text { Northern Politicians, Dr may not be the same again } \\
\text { Junaidu Mohammed }\end{array}$ & $\begin{array}{l}\text { Reported by KemyOguns in } \\
\text { Osun Defender, } 2^{\text {nd }} \text { December } \\
2013\end{array}$ \\
\hline 7 & 2013 & Nigeria will disintegrate if Jonathan contests in 2015 & $\begin{array}{l}\text { Daily Independent Friday, } \\
\text { March } 8^{\text {th }}, 2013\end{array}$ \\
\hline 8 & 2013 & $\begin{array}{l}\text { Former Chairman of The Yorubas are ungrateful kind of people, who do } \\
\text { PDP, Colonel Ahmadu not appreciate what others have done for them } \\
\text { Ali (rtd) }\end{array}$ & $\begin{array}{l}\text { Sun Newspaper, March 16, } \\
2013\end{array}$ \\
\hline 9 & 2014 & $\begin{array}{l}\text { Publicity Secretary of If the 2015elections are rigged, the party will not } \\
\text { All Progressive recognize the outcome and will go ahead and form a } \\
\text { Congress, Alhaji Lai parallel government } \\
\text { Mohammed }\end{array}$ & $\begin{array}{l}\text { Leadership } 21^{\text {st }} \text { November } \\
\text { 2014; Sahara Reporters } 22^{\text {nd }} \\
\text { November } 2014\end{array}$ \\
\hline 10 & 2014 & $\begin{array}{l}\text { Governor } \begin{aligned} & \text { Shema } \text { You should not be bordered with cockroaches of } \\
& \text { Ibrahim of Kastina } \text { politics. Cockroaches are only found in the toilet even } \\
& \text { at homes, if you see cockroaches in your house, Crush } \\
& \text { State }\end{aligned} \\
\text { them }\end{array}$ & $\begin{array}{l}\text { Reported by premium Times on } \\
19^{\text {th }} \text { November } 2014\end{array}$ \\
\hline 11 & 2014 & $\begin{array}{ll}\text { An Islamic cleric, } & \begin{array}{l}\text { Muslims, vote for Buhari. It is a sin to support a } \\
\text { non-Muslim }\end{array} \\
\text { ImaSadiq } & \end{array}$ & $\begin{array}{l}\text { Twitter handle, Saturday, } 27^{\text {th }} \\
\text { December } 2014\end{array}$ \\
\hline 12 & 2014 & $\begin{array}{l}\text { Those who vote for Jonathan and the PDP in } 2015 \text { will } \\
\text { be considered an enemy of the North }\end{array}$ & 15 October 2014 \\
\hline
\end{tabular}

\section{Conclusion}

Political campaigns by their nature, involve canvassing for votes in any modern society. Political communication as a tool involves a persuasive and strategic plan designed not only to provide consumers (voters) with information about the product (the politicians or political party) but to enhance that the consumers are persuaded to patronize the product so that the desired action is achieved. The paper concludes that hate speeches were used during the 2015 general elections campaign in Nigeria. The speeches were propagated by both the print and broadcast media. Hate speeches should not be elements of political messages during any electioneering cycle. This is because hate speeches negate the fundamental principles of democracy in any modern society. It is therefore recommended that political gladiators that engage in the use of hate speeches during electioneering should be penalized according to the electoral laws of the country. Ultimately, stringent punitive measures should be meted out to media outlets that punish or broadcast hate speeches as a form of deterrent for the sustenance of democracy in Nigeria.

\section{Recommendation}

It is the role of the press to educate, investigate and keep members of the public informed. In carrying out this function, objectivity in reporting should be the fulcrum of its masterpiece. It should be noted that because of the strategic role of the media in any society, the media can be dysfunctional. As a result of this, the press is expected to handle with care all issues of national importance. It is also expected to identify those and handle them with maturity and utmost care no matter how tempting the economic gains could be. The press as a major factor in this direction should take the issue of national unity and security with importance and fight to sustain Nigeria's corporate existence. Journalists should cross-check their facts and figures. There should be a difference between national interest and economic interest. Making a profit at the expense of the unity of the nation should be shunned by all.

Political parties should see their roles beyond merely canvassing for votes and winning elections. The true test of their success is the quality of their contribution to entrenching a culture of accountability, transparency, good governance, and ultimately, the entrenchment of a true and virile democratic culture.

The media should initiate and sustain column and programmes to educate and inform Nigerians on how to eschew 
political -motivated violence. The media and the public at large must renew their patriotic commitment to our collective national values, as long as the public is ready to play according to the rules, the security agencies should be ever ready to discharge their responsibility of ensuring a safe and secured environment.

\section{Competing Interests Statement}

The authors declare that there are no competing or potential conflicts of interest.

\section{References}

Ada, N., Alver, A., \& Fatma. (2008). Örgütsel_letisiminÖrgütselBaglılıkÜzerineEtkisi: Manisa Organize SanayiBölgesindeYer Alan ve malatSektörüÇalısanları̈UzerindeYapılanBirArastırma. EgeAkademikBakıs / Ege Academic Review, 8(2), 487-518.https://doi.org/10.21121/eab.2015121907

Avolio. (1999). Lado, Boyd \& Wright (1992).https://doi.org/10.1055/s-1999-2935

Lewis, A. (2008). Freedom for the thought that we hate: a biography of the first amendment. New York: Basic Books.

Adibe, O., \& Chibuwe, A. (2011) Social media, electioneering and sustenance of democracy in Africa: A SWOT analysis, A paper presented at the African Media and Democracy Conference (AMDC). Accra, AMDC publication.

Adibe, J. (2015). Fayose's advert: offensive or hate speech? Adopted from a paper presented at a round table on hate speech organized by the Kukahcentre, Abuja.

Ayo-Aderele, S. (2015).When hate speeches threaten an election. Retrieved from https://www.punching.com/democracy focus/when hate speeches threaten an election.

Benesch, S. (2015). Dangerous speech; a Proposal to prevent group Violence. World Policy, U.S.A

Bulter, P., \& Collins, N. (2006). Political Marketing: Structure and Process. European Journal of Marketing, 28(1), 19-34. https://doi.org/10.1108/03090569410049154

CITAD. (2015). Report of one-day stakeholders forum on hate speech and the 2015 elections in Nigerian. Retrieved from http://citad.org.report of one-day stakeholders forum on hate speech and the 2015 election in Nigeria

Duncan, T., \& Moriaty, S. E. (1998).A communication-based marketing model for managing relationships. Journal of Marketing, 62(2), 1-13. https://doi.org/10.2307/1252157

Ekanole, A. (2006). National Integration and the Survival of Nigeria in the 21st Century. Retrieved from $\mathrm{https://www.punching.com/democracy} \mathrm{focus} \mathrm{national} \mathrm{integration} \mathrm{in} \mathrm{21th} \mathrm{century}$

Ejiofor, L. (2007). Politics and Mobilization: A handbook of practical political behaviour. Abakaliki: Willy Rose and Appleseed Publishing Co.

Ezeibe, C. (2010). Inter-religious conflicts and crisis of development in Nigeria: Who benefits? Arts and Social Sciences Research Journal, 1(2), 112-132.

Ezeibe, C. (2015). Hate speech and electoral violence in Nigeria (Unpublished PhD Thesis, Department of Political Science, University of Nigeria, Nsukka).

Ezeibe, C. (2013). Hate speech and post-electoral violence in Africa. African Renaissance, 10(2), 75-87.

Environmental Right Action. (2003). Election Monitoring report on the ongoing Nigeria federal and State general elections. Abuja, Seed Publishing Co.

Falkinge, R. (2013). Acknowledging the important value of hate speech Falkinge.net. Falkinge, 21

Folarin, B. (1998).Theories of mass communication: an introductory text. Ibadan. Seed publishing co.

Habermas, J. (2006). Political communication in media society. Does democracy still enjoy an epistemic dimension? The impact of Normative theory on Empirical Research. Communication Theory, 16, 411-426. https://doi.org/10.1111/j.1468-2885.2006.00280.x

Holtzhausen, D. (2002). The effect of divisionalised and decentralized organizational structure on a formal internal communication function in a South African organization. Journal of Communication Management, 6(4), 323 -339. https://doi.org/10.1108/13632540210807152

Human Right Watch. (2004). Nigeria's 2003 elections the unacknowledged violence. http.//www.hrw.org. 
Ibeanu, O. (2009). Conceptualizing the specificities of direct capture in the 2007 elections in. J. Ibrahim and O. Ibeanu (Eds), Direct capture: The 2007 Nigerian elections and subversion of popular sovereignty. Lagos: Centre for Democracy and Development.

Independent National Electoral Commission. (2015). Result of 2015 Presidential Election in Nigeria. Abuja. INEC.

Goris, J. R. (2007). Effects of satisfaction with communication on the relationship between individual -job congruence and job performance/satisfaction. Journal of Management Development, 26(28), 737-752. https://doi.org/10.1108/02621710710777255

Kramer, M. W. (1999). Motivation to reduce uncertainty: are conceptualization of uncertainty Reduction theory. Management Communication Quarterly, 13(2), 305 -316.https://doi.org/10.1177/0893318999132007

Lewis, A. (2008). Freedom for the thought that we hate: a biography of the first amendment. New York: Basic Books.

Litterst, J. K., \& Eyo, B. (1982). gauging the effectiveness of formal communication programs: A search for the communication-productivity link. Journal of Business Communication, 9(2), 15. https://doi.org/10.1177/002194368201900202

Lakoff, R. (1990). Talking Power: The politics of language. New York: Basic Books.

Nockleby, T. (2000). Hate speech in Encyclopedia of the American constitution. Electronic Journal of Academic and Special librarianship.

National Human Rights Commission of Nigeria. (2015). A pre-election report and advisory on violence in Nigeria's 2015 general elections. Retrieved from http://www.NHRC.Ng.org.

Okorie, N., Oyesomi K., Oyero, O., Olatunji, R. W., \& Soola, E.O. (2014). Effective Use of Information Sources for Breast Cancer Care: Interplay of Mass Media and Interpersonal Channels. Journal of African Research in Business \& Technology, 4(10), 45.

Okunna, C., \& Omenugha, A. (2012). Introduction to Mass Communication (3rd Ed.). Enugu: New Generation Books.

Osaghae, E. (2005). A History of identities, Violence, and Stability in Nigeria.crises working press. NO.6.Queen Elizabeth House, University of Oxford. U.S.A

Seng, M., \& Hunt, H. (1986). The press and politics in Nigeria.A case of developmental journalism. Boston College Third World Law Journal, 6(2), 85-110.

Straus, S., \& Taylor, C. (2012). Democratization and electoral violence in Sub-saharan Africa, "1990-2008." In D. A. Oduraa (ed.), voting in fear: Electoral violence in sub-Saharan African. Washington, D.C. United States Institutes of Peace.

Sussan, B. (2012). An examination of social networking sites usage Among Muslims student in Islamic perspectives. International journalism of Engineering and Advanced Technology (WETA), 1(4) 273-278.

Tenuche, M. (2009). The language of politics and political behaviours, Rhetoric of President Olusegun Obasanjo and the 2007 general elections in Nigeria. Journal of Public Administration and Policy Research, 1(3) 047-054.

Ukwueze, C. I., \& Uche, A. (2015). The Rise of Hate and Peace Journalism in the Nigerian Democratic process. The place of the New Media. Communication Panorama African and Globe perspective, I (I), September October 2015 Maiden issue.

Wesinstein, J. (1999). Hate Speech, Pornography, and the Radical Attack on Free Speech Doctrine. Westview University Press.

Wantchekon, L. (1999). On the nature of first democratic elections. The Journal of Conflicts Resolution, 43(2), 245-258. https://doi.org/10.1177/0022002799043002008

Wilson, D. O. (1997). Diagonal Communication Links within Organizations. The Journal of Business Communication, 29, 129-141. https://doi.org/10.1177/002194369202900202

Woodward, M. (2016). Hate Speech, Dehumanization, Demonization and Violence: The Indonesia Islamic Defenders Front. Projekdialog.com.Projek dialog, 22 March, 2014, Web.12 Feb.2016. 


\section{Copyrights}

Copyright for this article is retained by the author(s), with first publication rights granted to the journal.

This is an open-access article distributed under the terms and conditions of the Creative Commons Attribution license (http://creativecommons.org/licenses/by/4.0/). 